\title{
Interpretations of footprints in the Bronze Age rock art of South Scandinavia
}

\author{
By PETER SKOGLUND ${ }^{1}$, COURTNEY NIMURA ${ }^{2} \&$ RICHARD BRADLEY $^{3}$
}

\begin{abstract}
The Scandinavian landscape is littered with postglacial outcrops, many of which carry engraved motifs. Although drawings of ships are the most often discussed, this paper focuses on representations of feet. In Northern Europe ship motifs are often associated with cosmologies based on the movement of the sun. In this paper we investigate whether drawings of feet could have been associated with the same worldview. We offer a number of interpretations of the images at two sites in different parts of Sweden: Järrestad 13:1 and Boglösa 138:1.
\end{abstract}

Keywords: Bronze Age, Scandinavia, prehistoric rock art, footprints, foot soles, ships, wheel crosses, sun crosses, sun, sea

\section{FOOTPRINTS IN SOUTH SCANDINAVIAN ROCK ART: AN INTRODUCTION}

The ship is the pre-eminent symbol of the Nordic Bronze Age, but it is commonly represented in rock art along with other motifs that have not received the same amount of attention. To some extent this is because they are more difficult to date - unlike seagoing vessels, they have no equivalents among decorated metalwork - but their distribution is more extensive than that of the better-known designs. While drawings of ships are strongly associated with the coast and the edges of major lakes, engraved footprints extend to inland regions in which other motifs are less common (Fig. 1). Here they can be associated with cup marks, wheel crosses, and occasional drawings of artefacts. A recent survey of rock art sites in Scandinavia calculated that there are over 4000 images of feet, the largest concentration of them in Sweden (Nimura 2015, 57, fig. 4.8). The paper studies their interpretation at different scales. The first considers the orientations of paired footprints in South Scandinavia as a whole, and the second considers the micro-topography of the two sites with the largest number of these images. It also investigates their organisation across the decorated surface.

\section{Bronze Age footprints and footgear}

Representations of feet differ from most other images, as many of them are life-size depictions of a particular part of the body. They generally occur as variants of two main types: the foot sole and the footprint (Fig. 2). Footprints are hollowed out, fully pecked naturalistic drawings of bare feet in which the toes are clearly indicated. Yet another type of footprint lacks these toes and represents the entire foot. Foot soles, on the other hand, are drawn in outline. Toes do not appear, but sometimes one or two transverse lines feature in these drawings (eg, Fig. 2c). They may show leather thongs that extend beneath the foot to keep a shoe, or rather a moccasin, in place (Marstrander 1963; Hald 1972; Malmer 1981; Skoglund 2013b). Such moccasins are known from the well-preserved Danish oak coffins of the Early Bronze Age (Hald 1972, 17-20). It is often assumed that when these images occur without the transverse line, they also represent footgear (Malmer 1981, 59-60) - this is especially clear when they are paired with foot soles associated with transverse lines. Where that element is missing the drawings could represent another type of shoe, formed by a piece of hide wrapped around the foot and kept in place by strings, one at the front and the other at the back. An example was recently found in a melting glacier at Jotunheimen in the south Norwegian mountains and has been ${ }^{14} \mathrm{C}$ dated to $1420-1260 \mathrm{cal}$ BC (Beta $228584,3070+-40$ BP 2 sigma (95\% probability) (cal BP 33703210) (Finstad \& Vedeler 2008).

\section{Past interpretations}

It has been difficult to interpret these images of feet, and for this reason their significance has been largely overlooked. This is perhaps because similar drawings are widely distributed outside Northern Europe and have been understood in many different ways (Gavaldo 2012; Bertilsson 2013). For a long time the depictions of feet in Scandinavia were considered as abstract signs that referred to a deity who could not be shown in full (Almgren 1962). They have also been regarded as symbols of fertility and protection (Marstrander 1963, 223-6). More recently, they have been thought to chart the movement of people across the decorated surface. 
The strongest argument for movement is the work of Kalle Sognnes in a region of sub-arctic Norway in which drawings of footprints are common. At Leirfall they seem to depict trails which can extend from one exposed surface to another. They lead to an outcrop which is decorated with a nonfigurative motif strikingly similar to those inside burial cists in the same region (Sognnes 2011). A similar claim was made by one of the writers in an account of Järrestad 13:1, where files of pecked or engraved footprints extend down the surface of the rock, leading from a small group of round barrows towards a bog (Bradley 1999). The connection between burials and footprints is found at other sites (Goldhahn 2011, 23), but at Järrestad there is the problem that some of these images may have been older than the mounds on the same site. In any case most of the feet are organised in pairs, as if they showed where people were standing rather than their path across the outcrop (Coles 1999, 175). Another interpretation draws on unusual cases in which feet are depicted inside decorated cists. Here it is easier to postulate a link between these images and the dead. The same applies to a few sites where lightly carved designs were covered by Bronze Age cairns or created immediately outside them (Goldhahn 2011; 2012).

The work of Katherine Hauptmann Wahlgren (2002) is important here, for she has studied the dimensions of the feet depicted on rock surfaces at Norrköping. They differ from one group of images to another. If they were drawn at life size, they might represent people of different ages, in particular, the young. There is similar evidence from sub-arctic Norway (Brox Nielsen 2005). In each case it suggests that these places played a role in rites of passage.

\section{ANOTHER INTERPRETATION - THE IMPORTANCE OF THE SUN}

Flemming Kaul (1998) has proposed an influential interpretation of Bronze Age cosmology based on the movement of the sun, which travels across the sky by day and returns to its point of departure during the night when it is carried by a ship. At different stages in its journey it is drawn by a horse or accompanied by a snake or eel. This scheme is illustrated by decorated metalwork. It also features in the rock art of South Scandinavia, although other narratives must be represented as well. There are many places where drawings of footprints can be found together with those of ships, some of which appear to be carrying the sun.

There are problems in taking Kaul's interpretation much further. These associations are recorded on or close to the shoreline, but the distribution of carved feet extends into inland areas. Does this rule out any connection with solar cosmology? That need not be true. At Ör, in the South Swedish Highland, there are many drawings of feet, and here a couple of paired foot soles occur in direct relation to a snake, a horse, and an arc that incorporates a cup mark. Even though ships are absent at this site, this composition includes nearly all the elements considered in Kaul's model, (Fig. 3; Skoglund 2006, 33-6).

If the movements of the sun were as significant in inland regions as they were at the coast, could this provide one explanation for the images of feet that are found in both those areas? In 2009 one of the writers explored this possibility (Bradley 2009, 195-7). John Coles (1999, 175) has long suggested that pairs of footprints and foot soles might mark the positions where people stood on special occasions. Was it possible that they were observing the movement of the sun across the sky? The original analysis had its limitations, for the sample of recorded images was small and no allowance was made for the distinction between footprints and foot soles. The main criterion was that they should appear in pairs.

The study published in 2009 suggested that images of feet faced in the general direction of the sun at different times of year. They did not extend outside the solar arc and, small as the sample was, it seemed to illustrate an emphasis on the winter and summer solstices. Figure 4 presents a new analysis of this evidence. Certain points need making at the outset. This study is confined to South Scandinavia and omits the sites in sub-arctic Norway. It is restricted to pairs of carved feet which might represent the position of someone standing on the rock, and single feet are not included. Nor are the images at Järrestad 13:1 or Boglösa 138:1, which are considered later in this article. They are omitted since they include so many drawings of feet that they would dominate the analysis. Figure 4 distinguishes between foot soles and footprints, and groups their orientations into $45^{\circ}$ bands. This is done for two reasons. As a recent commentator has observed, it is difficult to define exact alignments for drawings of this kind (Hesse 2013). In any case most of the records were based on the position of magnetic north, and since it is uncertain exactly when some of the surveys were undertaken it is 
impossible to correct their orientations to true north. By studying these results according to comparatively wide bands both these problems can be avoided.

The new scheme agrees with its predecessor in showing that virtually all the orientations fall within the solar arc. It is based on a larger sample of published records (Fett \& Fett 1947; Burenhult 1973; Coles 2000; 2005). Those for pairs of foot soles extend between north-east and north-west and the same is true of nearly all the depictions of footprints. It also reveals a significant difference between the two groups of images. Many of the drawings of footprints are directed towards the northeast, south-east and south, which are the positions of the morning sun during the summer months. The distribution of paired foot soles is quite different and emphasises the south-east and south - the direction where the sun is at its peak in winter. The reasons for this contrast are not clear. Footgear with transverse straps could have been worn in colder weather, or the two ways of showing feet might have been employed during different phases of the Bronze Age, in which case it would suggest that the significance of the solar cycle changed over the course of time. Another possibility is that they represent different groups of people - perhaps younger and older individuals - who took part in different ceremonies at these locations.

To take any of these arguments further it is necessary to examine particular sites at first hand. What are the best estimates of the orientations of these images? Were any contrasts in their alignments related to the techniques of making them? How were the images related to the contours of the rock? And were there differences of size which might reflect the ages of the people represented? A full analysis of this evidence could not be limited to drawings showing pairs of feet. Isolated foot soles and footprints needed to be studied too. So did the relationship between all these drawings and other images on the sites.

Järrestad 13:1 fits many of these criteria, as it includes one of the largest groups of feet anywhere in Scandinavian rock art (Coles 1999; Tilley 2004, chapter 4). It is towards the southern limit of their distribution, although others occur in Denmark and northern Germany (Glob 1969; Cappelle 2008). Another is Boglösa 138 (also referred to as Rickeby) further to the north in Uppland, which is equally well recorded (Coles 2000, 71-2, figs $49 \&$ 50; Broström 2007). In 2015 both sites were analysed on the ground in the light of the issues considered here.

\section{JÄRRESTAD 13:1}

The rock art occupies an outcrop measuring $40 \mathrm{~m}$ by $20 \mathrm{~m}$, sloping downwards towards the southeast. It forms part of a more extensive ridge, $5 \mathrm{~km}$ from the coast at a height of $55 \mathrm{~m}$ above sea level. In good weather the Baltic is visible from the top of the panel. The outcrop is composed of Cambrian sandstone and has a smooth but slightly wavy surface. The motifs extend over an area of $25 \mathrm{~m}$ by 20 $\mathrm{m}$ and include 77 foot soles, 92 footprints, 29 ships, 6 riders, 3 axes, 2 spirals, a human figure, and about 700 cup marks. There are also two paw prints which might be those of a bear (Bertilsson 2013, 249). A complete plan of the site was published by Coles (1999).

Beside the panel are three mounds between $4 \mathrm{~m}$ and $12 \mathrm{~m}$ in diameter and between 0.2 and $0.7 \mathrm{~m}$ high (Järrestad 13:2-4; records provided by the Archaeological Sites and Monuments database often referred to as FMIS or Fornsök: www.fmis.se). They have been excavated on two occasions and revealed six burials containing personal ornaments such as dress pins, a button, and a neck ring, dating these features to the later part of Montelius period V and the succeeding period VI, c. 800-500 BC (Althin 1945, 81-9; Stjernquist 1961, 79; Hjärthner-Holdar 1993, 130; Söderberg \& Hellerström $2003,50-4)$. One of the mounds is situated on the edge of the panel, suggesting a connection between the graves and the rock art. In that case the imagery could have been integrated with the cemetery around $800 \mathrm{BC}$.

\section{Dating}

The dating of footprints and foot soles at Järrestad has been discussed before (Skoglund 2013a), but a brief account of the arguments is needed here.

The case for placing the footprints in the Early Bronze Age depends on the relationship between footprints and axes dating from this period. There were two instances where a foot was engraved to resemble a flanged axe or possibly a palstave (for example Fig. 9e and Fig. 2f). In this case the toes were separated from the rest of the foot. In size and style these designs resemble axe heads which are shown with parts of their shaft. This type of 'visual punning' is quite common in the portrayal of feet and also occurs at Boglösa (see below). Another connection between feet and axes is 
the association between drawings of footprints, cup marks, and palstaves. Cup marks sometimes mark the positions of the heel, and a similar phenomenon also occurs with the three palstaves recorded on the site whose shafts terminate in knobs that are indicated in the same way (see Fig. 2d). At Järrestad such links between cup marks and other motifs may be an Early Bronze Age practice. By contrast, the foot soles are differently distributed about the site, and in the north-western part of the panel they are associated with ships dating from period V and the Pre-Roman Iron Age.

\section{Characteristics of the feet}

The lengths of the motifs have been plotted in Figure 5 (top), which distinguishes between foot soles and footprints. This graph identifies some important differences. The foot soles (light grey) are generally longer than the footprints (dark grey) - the average foot sole is $24.66 \mathrm{~cm}$ long, but the average length of a footprint is $20.59 \mathrm{~cm}$. The presence of a shoe will add a couple of centimetres to the size of the imprint, but the variety of smaller footprints cannot be explained in this way.

The standard deviation for the foot soles is $2.67 \mathrm{~cm}$, much less than that for the footprints. This implies that the group of foot soles represents a single group of people - their lengths suggest that they were adults. Cross-cultural studies have identified a consistent relationship between stature and foot size where the length of the foot is approximately $15 \%$ of the height of the human body (Fessler et al. 2005). At Järrestad this would suggest that we are looking at mean stature of $164 \mathrm{~cm}$, or $5 \mathrm{ft} 4 \mathrm{in}$. However, it is clear that the lengths of the footprints cluster around $20 \mathrm{~cm}$ and again at 17 $\mathrm{cm}$, indicating that the sample may include people who had not reached maturity. Perhaps the sample represents one group who could be regarded as adults, and another of younger individuals. The pairs of footprints, on the other hand, show a quite different pattern. Their lengths are $20 \mathrm{~cm}$ or more, identifying them as a specific subgroup on the site.

These observations can be compared with another study of engraved footprints and the people they might represent. Hauptman Wahlgren (2002, 227-8) concluded that most of the drawings of feet at Norrköping were between $15 \mathrm{~cm}$ and $26 \mathrm{~cm}$ in length, which suggested to her that children, youths, and women were represented in the rock art. Her analysis is based on data in the Archaeological Sites and Monuments database (www.fmis.se), which gives the range of feet lengths for each individual site. It could be misleading to distinguish between women and men on the basis of such estimates as the sizes of men's and women's feet overlap. Interestingly, foot soles less than $20 \mathrm{~cm}$ long are represented in her study - a very different pattern than that observed at Järrestad (Hauptman Wahlgren 2002, 227-8; cf. Skoglund 2006, 22).

To conclude, Järrestad is the only site in Sweden where the individual feet have been measured precisely and the pattern confirms earlier suggestions that children's feet are represented on the panels. As we shall see, the same does not apply to Boglösa.

\section{Orientations}

There is a precedent for the analysis of orientations at this site. In 2012 Mörner published a study of Järrestad 13:1 in which he claimed that the carved footprints were directed towards the position of the rising sun on the shortest day of the year. His analysis has its limitations. He used an early survey of the site published by Althin in 1945. This was not the most recent record, nor was it the most comprehensive. Since then the images have been documented by Burenhult (1973) and again by Coles (1999) whose record provided the basis for our work there. In any case Mörner's analysis may be based on a false premise for the title of his article refers to a 'strict solar alignment'. That suggests that the site was used for astronomical observations. In the light of what has been written about Bronze Age cosmology this could be entirely misleading. The same applies to the critique of his views by Hesse (2013) which appeared in a subsequent issue of the same journal.

In his response to Mörner's article Hesse $(2013,2322)$ states that during the Nordic Bronze Age the midwinter sunrise could be seen from Järrestad at a bearing of between $133.8^{\circ}$ and $134.1^{\circ}$. That overlaps with the orientation of a small proportion of the drawings of feet, but the majority are directed up to $10^{\circ}$ further to the north (Fig. 6a). This applies to both footprints and foot soles. The fact remains that apart from a few drawings of footprints that were ascending the rock, the great majority were confined to a band which was only $20^{\circ}$ wide. They would have faced the sun, but up to a month after the solstice when conditions in the Swedish winter began to improve. Interestingly, during the early historical period this was considered as the start of the Scandinavian New Year (Nordberg 2006). At the same time there are other issues to consider. The carvings are directed towards a 
comparatively short section of the Baltic which can be recognised on the horizon (Fig. 7). They also extend down the gradient of the rock, framed by the pattern of natural cracks visible in its surface. They ran parallel to them and these natural features clearly influenced the organisation of the images (see Fig. 7 inset). For Coles $(1999,174)$ they were used to position the separate groups of images. It seems that all these features were important. The result may have been an accommodation between each of these elements. At all events people standing in the positions indicated by the pairs of footprints would have been able to observe the relationship between the water and the sun. That is an important feature of Kaul's cosmology. This effect would be especially striking since rock art is best seen in low light (Coles 2004, 204).

\section{BOGLÖSA 138:1}

The panel at Boglösa includes 93 foot soles, 16 footprints (plus one that is both fully carved and outlined), 51 ships, 18 circles, 6 humans, 2 animals, a 'mantle' or 'chair', and about 94 cup marks. The outcrop is approximately $19 \mathrm{~m}$ in diameter and has an unusual domed profile (Fig. 8c); this is a different shape from the surfaces on which much rock art was carved in Sweden. Its summit is at about 22.9-25.2 metres above sea level (Ling 2013,32) and the site is in the middle of a plain. To the north-west the rock slopes steeply down towards an expanse of flat ground (Fig. 8a). This is where the sea would have been during the Late Bronze Age (Fig. 8b; Ling 2013, 33, fig. 14.). There are a number of other rock art sites in the area, but none includes the same quantity of footprints as Boglösa 138:1. In common with Järrestad, there were burials and settlements nearby, but there is no dating evidence to relate them to this panel.

\section{Dating}

Based on Kaul's typology, it appears that the earliest ships were on the upper part of the outcrop. Some are typical of Early Bronze Age period I, but the majority of the ships can be assigned to periods II-III. The later vessels were towards the bottom of the panel. They probably date from Montelius period V (the Late Bronze Age). Thus people began to create images towards the highest point and continued to make new images as the retreating water exposed more of the rock (Ling 2013, 32-3).

As at Järrestad, there may be a chronological distinction between footprints and foot soles. At Boglösa most of the foot soles are towards the bottom of the panel where they can be arranged in pairs, some of which resemble 'wheel crosses' or 'sun crosses' (these terms are generally used interchangeably; Fig. 9a). They could not have been made there until the Late Bronze Age. Single feet, however, are found closer to the summit of the outcrop and they might have been created before that time.

\section{Characteristics of the feet}

There are other differences between the two sites. At Boglösa foot soles dominate the panel (94 foot soles versus 16 footprints), but Järrestad has almost the same number of both motifs. At Boglösa the quantities of pairs and single feet are roughly comparable (33 pairs versus 40 individual feet; 4 are indeterminate), but Järrestad has many more single feet than pairs (28 pairs versus 113 individual feet). At Boglösa the mean length of the foot soles is $23.42 \mathrm{~cm}-$ only slightly less than the figure for Järrestad $(24.66 \mathrm{~cm})$ (Fig. 5, bottom). The average sizes of the footprints are nearly identical -20.24 $\mathrm{cm}$ at Boglösa and $20.6 \mathrm{~cm}$ at Järrestad - but at Boglösa there is much less variation. For that reason it is unlikely that children are represented.

Unlike the evidence from Järrestad, the drawings of feet at Boglösa include some oddities. At times the pairs of foot soles are hard to distinguish from wheel crosses or sun crosses (Fig. 9a). This is a phenomenon that occurs across South Scandinavia. Such 'visual punning' extends to the drawings of feet and ships at Boglösa. Figure $9 \mathrm{~b}$ shows how a single foot forms the body of a ship; the keel also follows its outline. Another attempt to carve a 'foot-ship' (Fig. 9c) is less successful but still is intriguing. Here a small ship collides with a foot sole, and two parallel lines extending from the heel could identify the gunwale and the keel. Another footprint is found within a circle, and just above it a foot sole with a cup mark heel resembles the prow of a ship (Fig. 9d). Visual puns like these are not uncommon. As we have seen, at Järrestad some of the footprints closely resemble a flanged axe, or possibly a palstave (Fig. 9e; Skoglund 2013a, 692-3; Bertilsson 2013), but the visual puns noted at 
Boglösa combine images of feet, ships, and the wheel cross. They suggest a close relationship between the sun, the sea, and the rock itself.

\section{Left or right?}

It is not always straightforward to decide whether a left or right foot is being shown, but most of those at Boglösa and Järrestad can be identified - of the 36 single feet that could be determined at Boglösa, only 9 are left feet and 27 are right feet: a striking imbalance. It was at Boglösa that the authors took a long pause when faced with a line of right feet that marched down the sloping face of the outcrop following a dry stream channel (Fig. 10). When representing a pair of feet, the maker must show both left and right, but when they appear individually, how did one decide which foot to represent?

The significance of 'left' and 'right' is much discussed in anthropology. At many points in the recent and ancient past communities have assigned meaning to right-handedness and left-handedness and linked them with concepts of good and bad respectively. In the Phaedrus, Plato creates a tidy ontological chain through the metaphor of the human soul. The soul is compared to a charioteer with two horses: the right-hand horse is light and represents all that is noble and rational, but the left-hand horse is dark and irrational. These distinctions appear in countless anthropological examples (Hertz 1973) and in some cases they condition daily practice. In an Indian example quoted by Alpenfels (1955) the right hand is used for 'clean' activities such as eating, and the left hand is for 'dirty' activities like washing. Although right and left are often discussed in terms of hands, this distinction extends to the sides of the body, and, of course, to feet. In Roman Britain, left and right feet are represented by shoe brooches and were associated with the same superstitions. In Roman belief it was bad luck to step 'into a banqueting room with the left foot first' (Eckardt 2015, 231). Single feet were also important in the past. Their significance is documented in early Irish sources and in the Classical world. In some cases the use of only one shoe 'seems to have a magical significance denoting a critical transition from one state of being to another' (Waddell 2014, 77). It was especially important in the passage between death and the afterlife.

Left and right are equally important in Kaul's $(1998,259)$ reconstruction of Bronze Age cosmology in Scandinavia: in his scheme the sun moves from left to right across the sky. Hidden beneath the sea, it travels in the opposite direction during the hours of darkness. Could these notions be reflected in rock art? Was the right foot associated with the day and the left foot with the night? A reason for thinking in these terms is the difficulty of distinguishing between pairs of foot soles and wheel crosses/sun crosses. Such pairs of feet could refer to the complete 24-hour cycle. So would a sun cross.

\section{Orientations}

The orientations of feet at Boglösa differ from those at Järrestad; in fact, they are almost the mirror images of one another (Fig. 6b). Most of the feet at Boglösa face north-west and are directed down the steepest part of the rock. At Järrestad, the majority of feet point south-east, following a gentler gradient. Although their positions are fixed, their arrangement on the panel hints at movement across the surface from somewhere to somewhere else. Metaphors of movement are present where pairs of feet imitate wheel crosses (Fig. 9a). They also apply to feet that merge with ships (Fig. 9b-d). Those wheel crosses face in the same directions as the pairs of foot soles (Fig. 11).

The drawings of feet at Boglösa are predominantly oriented between $310^{\circ}$ and $340^{\circ}$ : this would have been in the general direction of the midsummer sunset, which is towards the north-west, but in contrast to the carvings of feet at Järrestad, they extend across an arc of $70^{\circ}$, although the majority are distributed over just $30^{\circ}$. In the circumstances it would be wrong to think in terms of a 'strict solar alignment'. In fact about half fall just outside the northernmost limit of the solar arc at $315^{\circ}$. Their locations could have been influenced by the slope of the rock which would have made it very difficult for observers to stand at an angle to the steepest gradient. The precision claimed by Mörner at Järrestad was not necessarily important.

Perhaps it is more significant that at Boglösa they are facing the Bronze Age sea (Fig. 8; Ling 2013, 33, fig. 14.1). It is possible that what is being expressed is a more complex relationship between water, the sun, feet, and a human audience. Each of these elements had a part to play in a wider Bronze Age worldview. Feet could be combined in pairs to resemble sun crosses; they could merge with ships and could travel towards the sea. When choosing whether or not to represent a left or right 
foot, it is possible that the maker was devising a metaphor for a movement of the sun. All those elements were bound together by visual puns.

\section{CONCLUDING THOUGHTS}

This paper began by drawing together the published records of pairs of human feet in the rock art of South Scandinavia. This was necessarily a two-dimensional analysis for it could not take into consideration the shapes and contours of the surfaces on which it was made. Nor could it consider the natural cracks, fissures, and mineral veins in the surface of the stone or the channels made by running water (Bradley et al. 2002). This is unfortunate since most or all of these elements were present before such places were selected for special treatment. Indeed they may have been among the reasons why they were chosen. For instance, the lines of foot soles at Järrestad 13:1 may have been created there because the surface of the rock was already marked by cracks which extended in the direction of the midwinter sunrise. This way of integrating natural features of the rock into the overall compositions is a well-known phenomenon in north Scandinavian rock art (Helskog 1999; 2004; Gjerde 2010). Similarly the resemblance between Boglösa 138:1 and a round cairn may have influenced the decision to embellish this particular outcrop, and the orientation of some of the engraved images could have been influenced by the direction in which water travels down the surface of the stone.

It is clear that there can be no single interpretation of the depictions of human feet in South Scandinavian rock art, nor were they organised in the same ways in the cases considered in detail here. That is hardly surprising as they occur in quite different regions with their own styles of petroglyphs. At the two sites where fieldwork was conducted, there are numerous similarities and differences. At Järrestad it is possible that the feet represent people of different ages, whereas at Boglösa the foot soles and footprints should be those of adults. Visual puns are common: wheel or sun crosses indistinguishable from pairs of foot soles are present at both locations. Their orientations, though markedly different, could reference solar 'alignments' at either the midwinter or midsummer solstice. At each site they also extend downslope in the direction of the sea. Around Järrestad and Boglösa there were plenty of other surfaces suitable for making art and many of them were embellished, yet none has the concentration of footprints represented at these two sites.

At the same time it is evident that they lend themselves to a more complex analysis than has been offered before. On the basis of published sources there does seem to be a significant relationship between the pairs of carved footprints and the position of the sun which played an important role in the belief system of the Nordic Bronze Age. They transcend the conventional distinction between coastal areas with their drawings of ships, and inland regions in which the variety of designs was more restricted. At the same time, the detailed studies presented here suggest that there were other features that have to be considered: the different ways of rendering feet; the possibility that these drawings referred to people of different ages; the evidence for cross-references between individual motifs and chronologically diagnostic artefacts; and the distinction between left and right that is so important in social anthropology.

The micro-topography of the decorated surfaces was equally significant. If these motifs choreographed public ceremonies and showed where people should stand, there was a necessary accommodation between the directions in which they were facing and the gradient of the rock. Rather than looking obsessively at the sun, the people who visited these sites may have been equally concerned with the sea. These are matters for debate. What matters is that these distinctive designs can shed new light on the practices that took place at rock art sites and, just possibly, on who the participants were and how their activities were organised on the decorated surface.

Acknowledgments: The authors wish to thank the Prehistoric Society for funding the fieldwork that provided the data for this paper. We would like to thank Anna Wessman for helping us plan the fieldwork in Uppland. We would also like to thank Johan Ling and Catarina Bertilsson for allowing us to reproduce Figure $8 \mathrm{~b}$ and Figure $2 \mathrm{~d}$ respectively, and Craig Williams and Chris Green for their advice with the graphs.

\section{BIBLIOGRAPHY}

[BIBL]Almgren, B. 1962. Den osynliga gudomen. In Proxima Thule Sverige och Europa under forntid och medeltid. Hyllningsskrift till H. M. Konungen den 11 november 1962 utgiven av Svenska Arkeologiska Samfundet, 53-71. Stockholm: Norstedts förlag 
Alpenfels, E.J. 1955. The anthropology and social significance of the human hand. Artificial Limbs 2(2), 4-21

Althin, C.-A. 1945. Studien zu den bronzezeitlichen Felszeichnungen von Skåne 1-2. Lund: Gleerup

Bertilsson, U. 2013. Footprints on the rock faces - following the tracks of cosmological archetypes for millennia of prehistory. In S. Bergerbrand \& S. Sabatini (eds), Counterpoint: Essays in archaeology and heritage studies in honour of Professor Kristian Kristiansen, 243-52. Oxford: British Archaeological Report 2508

Bradley, R. 1999. Dead soles. In A. Gustafson \& H. Karlsson (eds), Glyfer och rum - en vänbok till Jarl Nordbladh, 661-6. Gothenburg: Gotarc Series A3

Bradley, R. 2009. Image and Audience: Rethinking prehistoric art. Oxford: Oxford University Press

Bradley, R., Jones, A., Nordenborg Myhre, L. \& Sackett, H. 2002. Sailing through stone: Carved ships and the rock face at Revheim, Southwest Norway. Norwegian Archaeological Review $35,109-18$

Broström, S.-G. 2007. Hällristning Rä̈ 138:1 vid Rickeby i Boglösa socken. Redogörelse över ny dokumentation 2006 utförd av Sven-Gunnar Broström med bidrag av Kenneth Ihrestam och Roger Wikell. Unpublished Botark-rapport 2007:1; Raä dnr: 321-4290-2008

Brox Nielsen, T. 2005. Vedrørende en bergkunstlokalitet i Stjørdalen. Trondheim: Norges teknistnaturvitenskkaplige universitet

Burenhult, G. 1973. The Rock Carvings of Götaland, Vol. 2. Lund: Acta Archaeological Lundensia

Cappelle, T. 2008. Bilderwelten der Bronzezeit. Felsbilder in Norddeutschland und Skandinavien. Mainz: Phillipp von Zabern

Coles, J. 1999. The dancer on the rock: Record and analysis at Järrestad. Proceedings of the Prehistoric Society 65, 167-87

Coles, J. 2000. Patterns in a Rocky Landscape: Rock carvings in south-west Uppland. Uppsala: Department of Archaeology and Ancient History, University of Uppsala

Coles, J. 2004. Bridge to the outer world: Rock carvings at Bro Utmark, Bohuslän, Sweden. Proceedings of the Prehistoric Society 70, 173-205

Coles, J. 2005. Shadows of a Northern Past: Rock carvings of Bohuslän and Ostfold. Oxford: Oxbow

Eckardt, H. 2015. Shoe brooches in Roman Britain. In H. Eckardt \& S. Rippon (eds), Living and Working in the Roman World, 217-34. Portsmouth, RI: Journal of Roman Archaeology Supplementary Series 95

Fessler, D.M.T., Haley, K.J. \& Roshni, D.L. 2005. Sexual dimorphism in foot length proportionate to stature. Annals of Human Biology 32(1), 44-59

Fett, E. \& Fett, P. 1947. Sydvestnorsk Helleristinger. Rogaland og Lista. Stavanger: Stavanger Museum

Finstad, E. \& Vedeler, M. 2008. En bronsealdersko fra Jotunheimen. Viking LXXI, 61-70

Gavaldo, S. 2012. Le impronte di piedi nell' arte rupestre camuna e I confronti in altre fonti iconographische. Preistoria Alpina 46(2), 127-30

Gjerde, J.M. 2010. Rock Art and Landscapes: Studies of Stone Age rock art from Northern Fennoscandia. Troms $\varnothing$ : Universitetet i Troms $\varnothing$

Glob, P.V. 1969. Helleristninger i Danmark. Copenhagen: Jysk Arkeologisk Selskab Skrifter Bind VII

Goldhahn, J. 2011. Törnsfall - hällbilder vid ett röse och ett röse mid hällbilder. Kalmar: Linnéuniveritetet

Goldhahn, J. 2012. In the wake of a voyager: Feet, boats and death rituals in the North European Bronze Age. In A. Meirion Jones, J. Pollard, M. Allen \& J. Gardiner (eds), Image, Memory and Monumentality, 218-32. Oxford: The Prehistoric Society

Hald, M. 1972. Primitive Shoes: An archaeological-ethnological study based upon shoe finds from the Jutland peninsula. Copenhagen: National Museum

Hauptman Wahlgren, K. 2002. Bilder av betydelse: hällristningar och bronsålderslandskap $i$ nordöstra Östergötland. Lindome: Bricoleur Press

Helskog, K. 1999. The shore connection: Cognitive landscape and communication with rock carvings in Northernmost Europe. Norwegian Archaeological Review 32(2), 73-94

Helskog, K. 2004. Landscapes in rock art: Rock art and ritual in the old European North. In C.

Chippindale \& G. Nash (eds), Pictures in Place: The figured landscapes of rock art, 265-88.

Cambridge: Cambridge University Press 
Hertz, R. 1973. The pre-eminence of the right hand. In R. Needham (ed.), Right and Left: Essays on dual symbolic classification, translated by R. Needham \& C. Needham, 3-31. Chicago, IL: University of Chicago Press

Hesse, R. 2013. Strict solar alignment of Bronze Age rock carvings in SE Sweden? Critical remarks on an archaeoastronomical case study. Journal of Archaeological Science 40, 2321-5

Hjärthner-Holdar, E. 1993. Järnets och järnmetallurgins introduktion $i$ Sverige. Uppsala: Uppsala Universitet

Kaul, F. 1998 Ships on Bronzes: A study in Bronze Age religion and iconography. Copenhagen: National Museum

Ling, J. 2013. Rock Art and Seascapes in Uppland. Swedish Rock Art Series Volume 1. Oxford: Oxbow

Malmer, M.P. 1981. A Chorological Study of North European Rock Art. Stockholm: Vitterhets-, historie- och antikvitetsakademien

Marstrander, S. 1963. Østfolds jordbruksristninger 1-2. Oslo: Universitetsforlaget

Mörner, N.-A. 2012. Strict solar alignment of Bronze Age rock carvings in SE Sweden. Journal of Archaeological Science 39, 3301-5

Nimura, C. 2015. Prehistoric Rock Art in Scandinavia: Agency and environmental change. Swedish Rock Art Series Volume 4. Oxford: Oxbow

Nordberg, A. 2006. Jul, disting och förkyrklig tideräkning Kalendrar och kalendariska riter i det förkristna Norden. Uppsala: Kungl. Gustav Adolfs Akademien för svensk folkkultur

Plato. Phaedrus. 360 BC. Translated by Benjamin Jowett (1817-93). Blacksburg, VA: Virginia Tech (ebrary book 2001)

Skoglund, P. 2006. Hällristningar i Kronobergs län: Motiv, myter och dokumentation. Lund: Lund University

Skoglund, P. 2013a. Iron Age rock art: A view from Järrestad in south-east Sweden. European Journal of Archaeology 16(4), 685-703

Skoglund, P. 2013b. Images of shoes and feet: Rock art motifs and the concepts of dress and nakedness. Norwegian Archaeological Review 46(2), 159-74

Söderberg, B. \& Hellerström, S. 2003. Centralbygdens sociala landskap: Sten- och bronsålder i Järrestad. In B. Söderberg (ed.), Järrestad: Huvudgård i centralbygd, 21-82. Stockholm: National Heritage Board

Sognnes, K. 2011. These rocks were made for walking: Rock art at Leirfall, Trøndelag, Norway. Oxford Journal of Archaeology 30, 185-205

Stjernquist, B. 1961. Simris. 2, Bronze Age Problems in the Light of the Simris Excavation. Lund: Lund University

Tilley, C. 2004. The Materiality of Stone. Oxford: Berg

Waddell, J. 2014. Archaeology and Celtic Myth. Dublin: Four Courts Press 


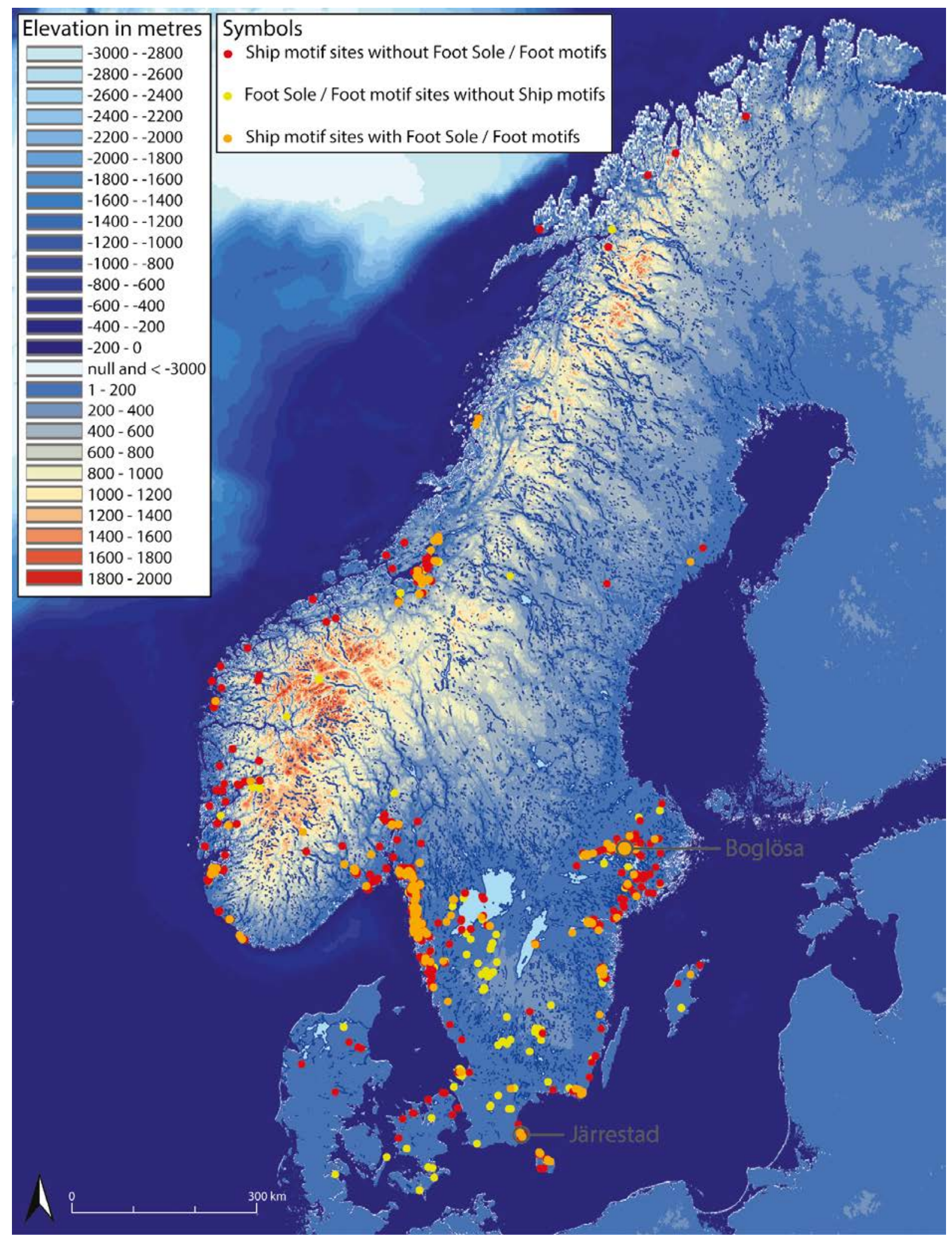

Figure 1. Map of the distribution of ships, foot sole, and footprint motifs in Scandinavia with the two key sites mentioned in the text (after Nimura 2015, 57, fig. 4.8) 

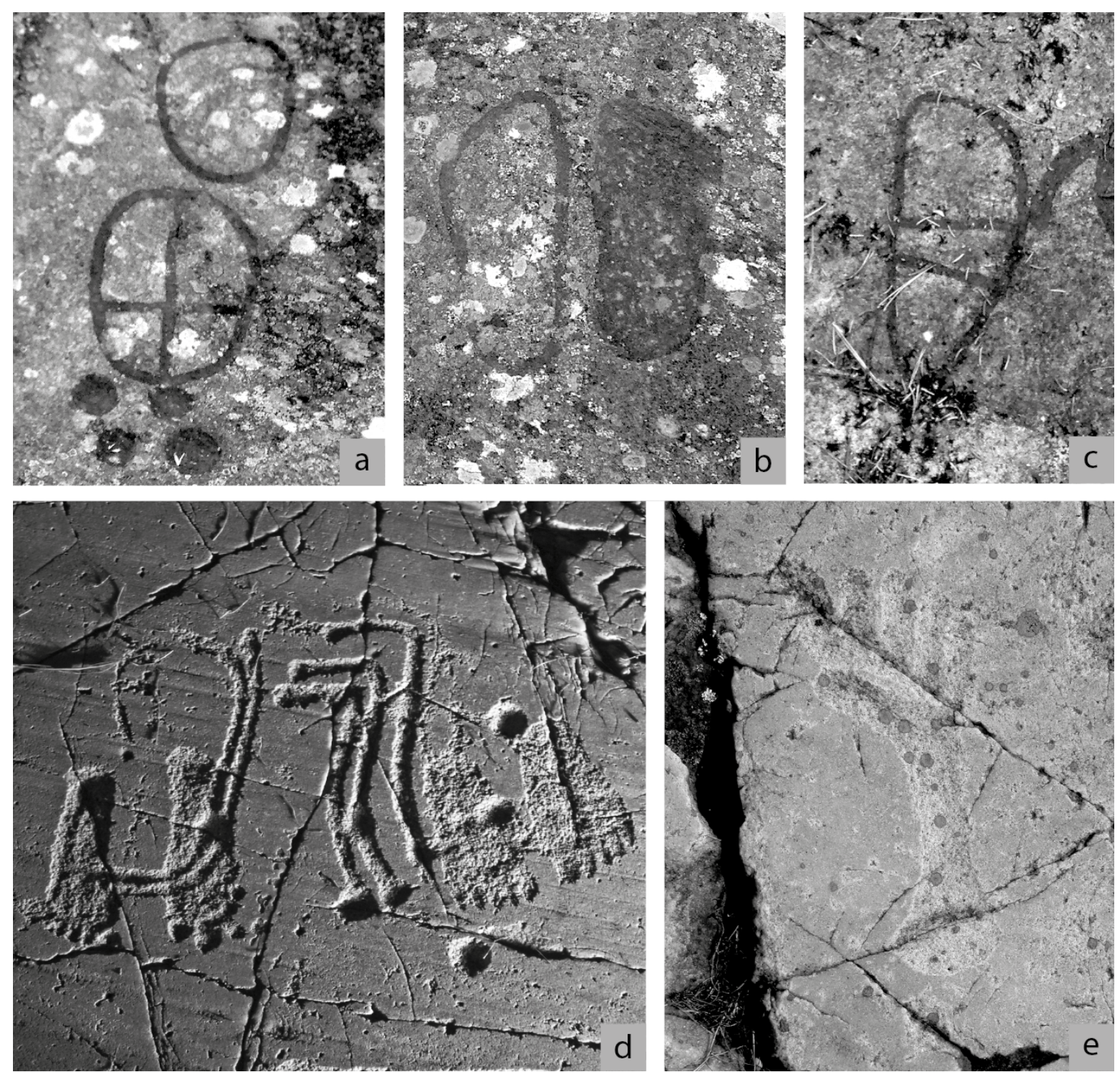

Figure 2. Examples of the variety of feet representations that can be grouped into two main types: foot soles and footprints (bare feet). Photos a-c: C. Nimura; d: C. Bertilsson (Source: Swedish Rock Art Research Archives id: 3977); e: P. Skoglund

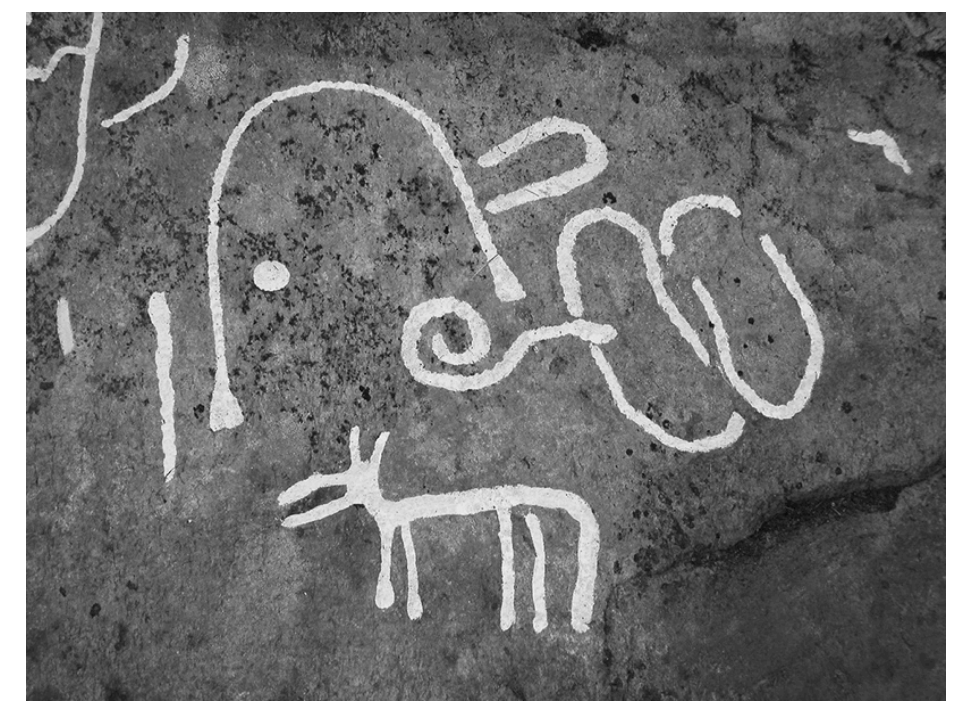

Figure 3. A pair of foot soles directly related to a snake, a horse, and an arc that incorporates a cup mark at Ör (Ör 21:4). This composition may reflect similar ideas to those outlined in Kaul's model in an area where there are no ships. Photo: P. Skoglund 


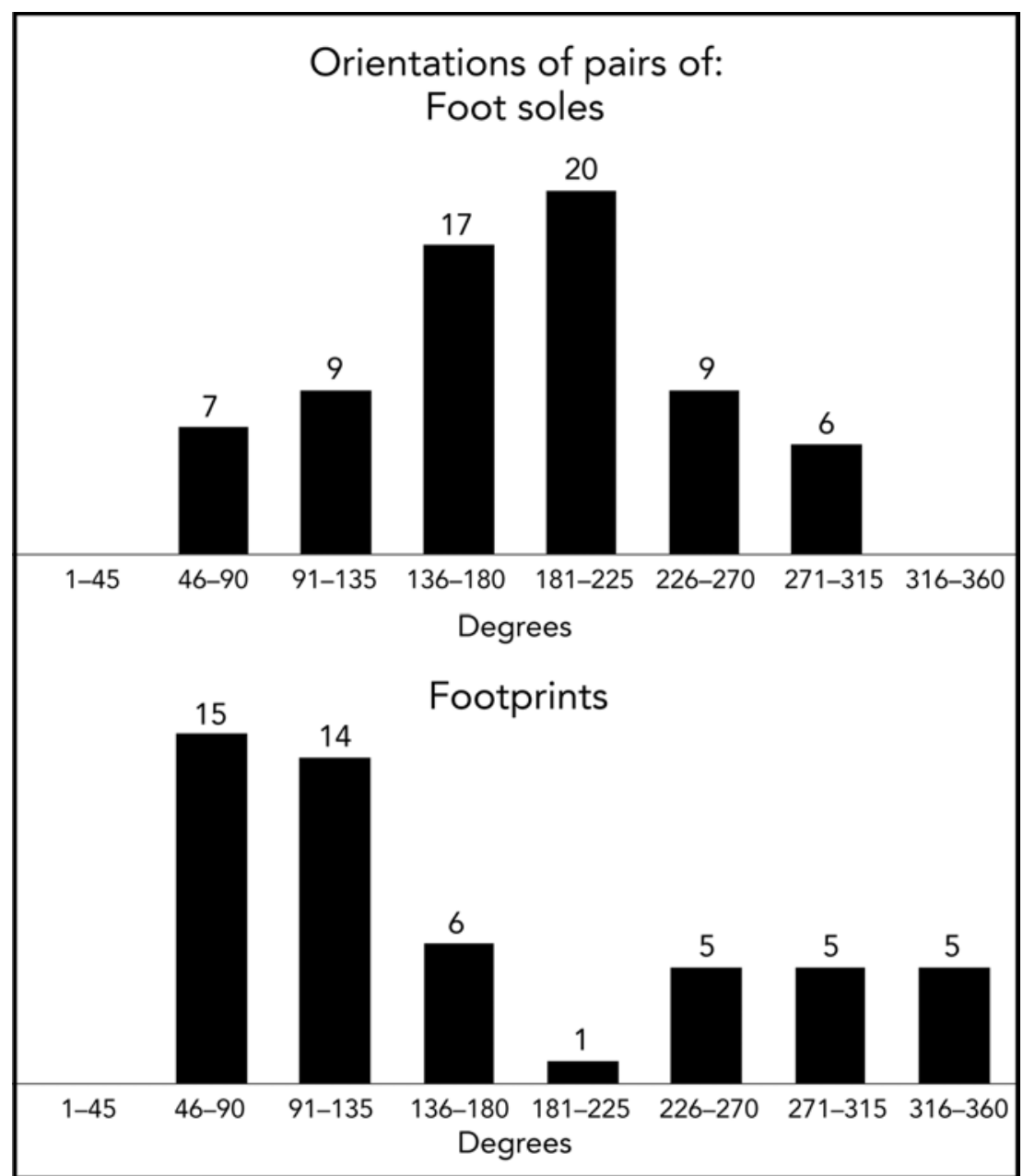

Figure 4. The orientations of pairs of foot soles and footprints based on published sources, grouped in $45^{\circ}$ intervals. The sample omits Järrestad 13:1, Boglösa 138:1, and Ör where the exceptional number of images would dominate the overall pattern. For the same reason examples in sub-arctic Norway are not included here 


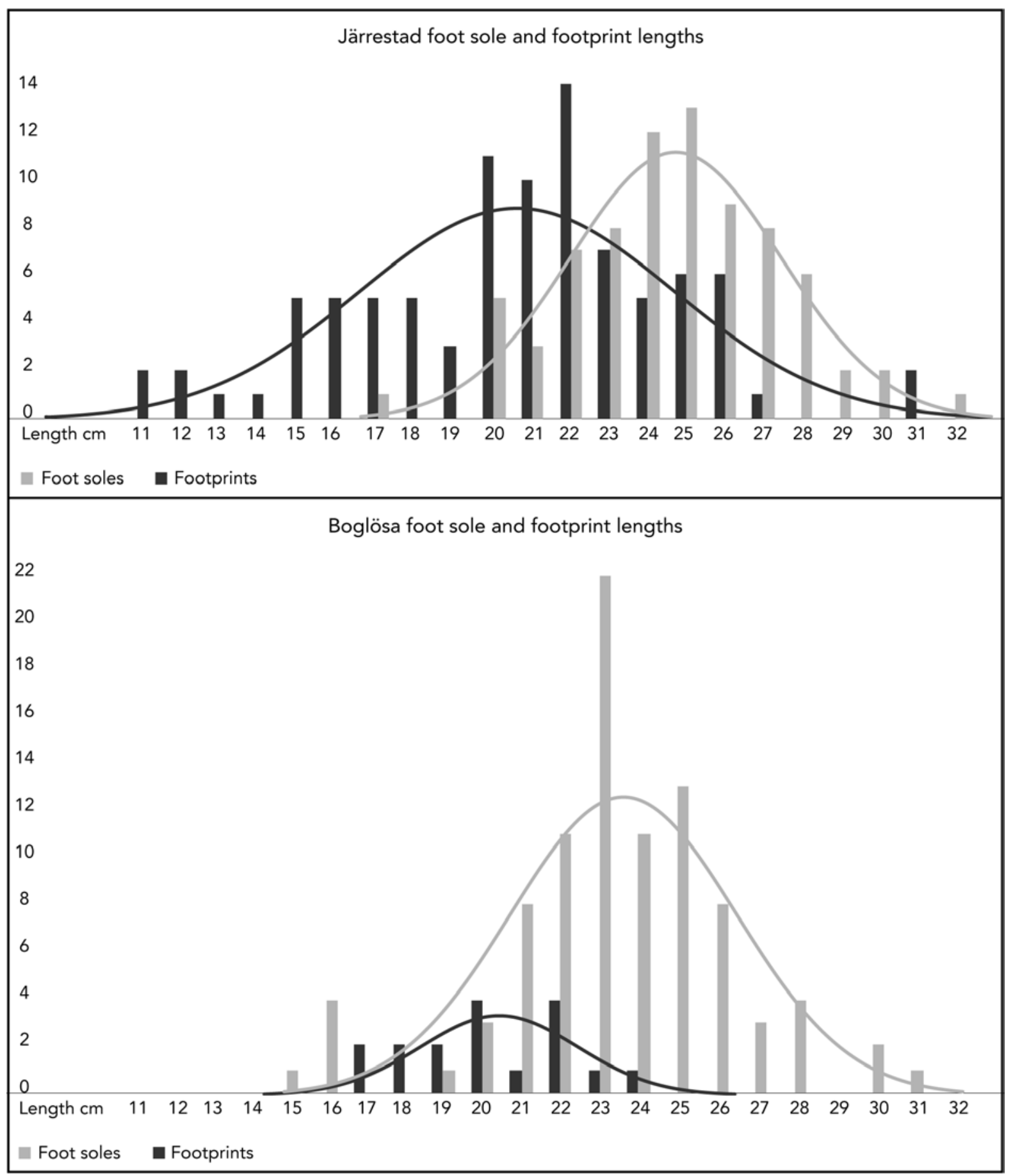

Figure 5. The lengths of foot soles and footprints at the two sites with a normal distribution curve based on the position of the mean. Järrestad 13:1) Foot sole $\sigma: 2.67$, mean: $24.66 \mathrm{~cm}$; Footprint $\sigma$ : 4.04, mean: $20.59 \mathrm{~cm}$. Boglösa 138:1) Foot sole $\sigma: 2.90$, mean: $23.42 \mathrm{~cm}$; Footprint $\sigma: 2.02$, mean: $20.24 \mathrm{~cm}$ 


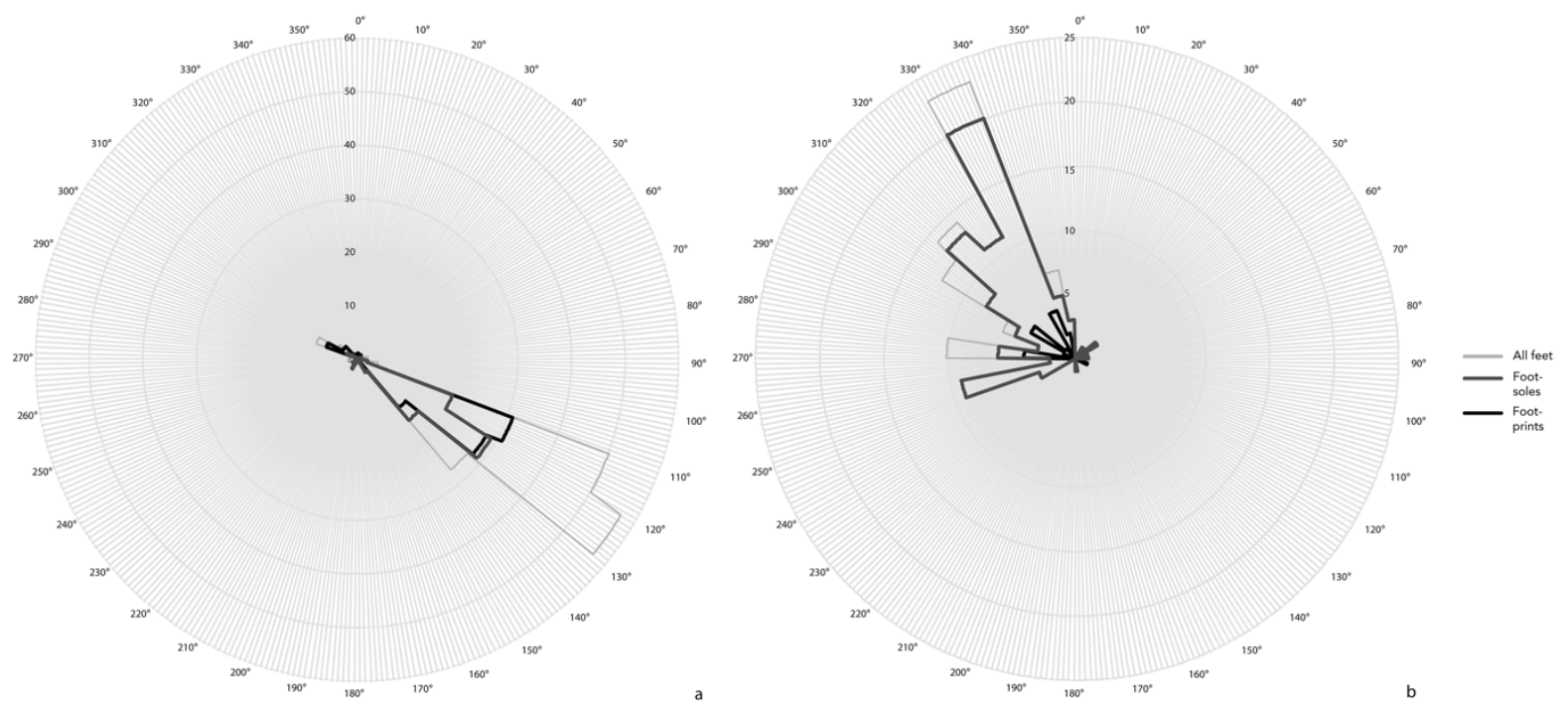

Figure 6. The orientations of foot motifs broken down into foot soles and footprints at a) Järrestad 13:1 and b) Boglösa 138:1. Each foot motif is counted individually and grouped in $10^{\circ}$ intervals

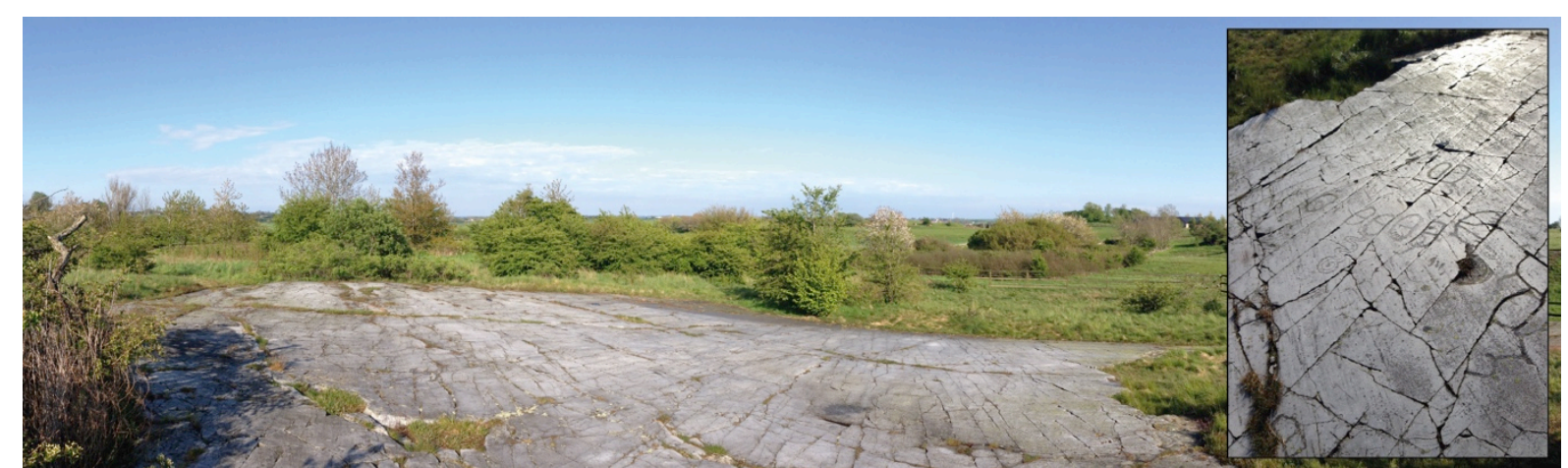

Figure 7. The view from the top of the rock art panel at Järrestad 13:1. The sea is visible from a number of locations on the horizon. The inset shows how the feet are framed by the natural cracks on the panel. Photos: C. Nimura 

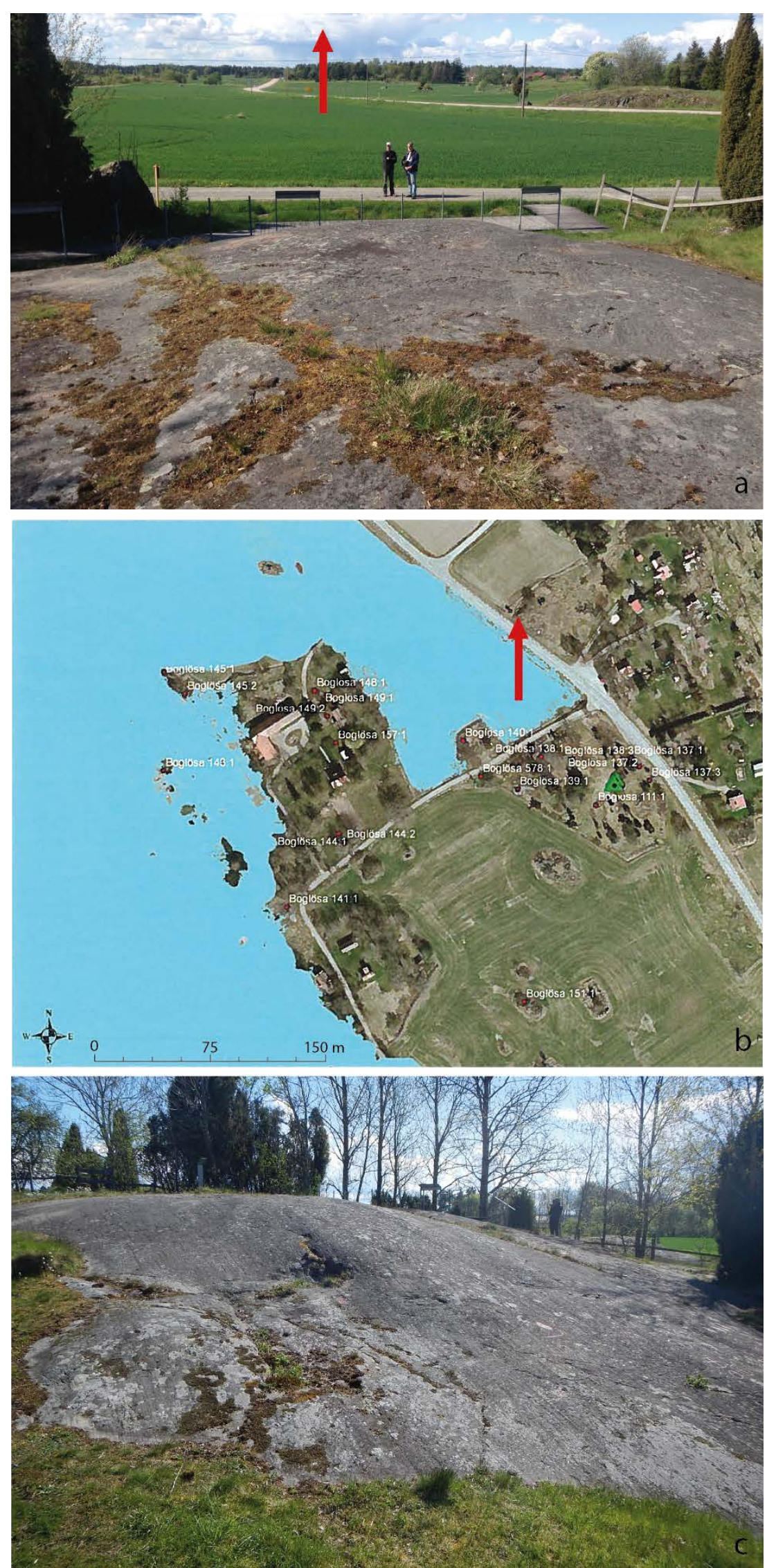

Figure 8. a) The view when standing at the crest of the domed rock outcrop Boglösa 138:1 looking out towards the location of the Bronze Age sea. Photo: C. Nimura. b) The surrounding rock art is shown as red dots (reproduced from Ling 2013, 33, fig. 14.1). The red arrows in a and b illustrate the direction of view from the carved rock. c) The domed rock showing the flat, steeply sloping rock face where the majority of the footprints have been carved. Photo: P. Skoglund 

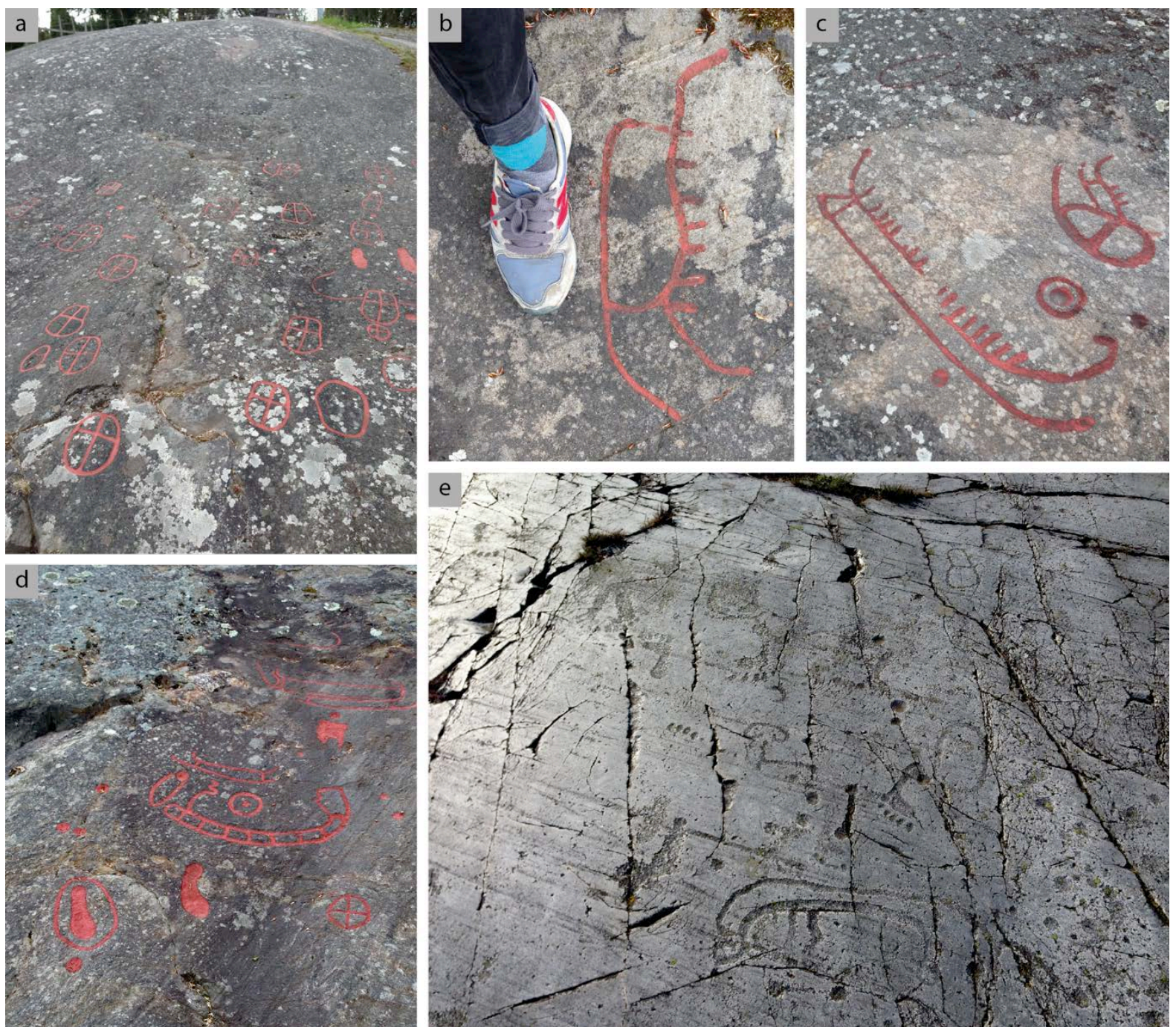

Figure 9. Visual 'puns' at Boglösa 138:1: a) the largest concentration of foot soles, many of which closely resemble wheel crosses; b) a 'foot-ship' with a human foot (UK size 4) for scale; c) a ship colliding with a single foot sole, which has a protruding line that could be an upturned keel at the crest of the panel; d) a footprint within a circle, and above it a foot sole with a cup mark as its heel which resembles the prow of a ship; e) a group of motifs at Järrestad 13:1, including bare feet that resemble flanged axes or palstaves (see also Fig. 2f). Photos: C. Nimura 


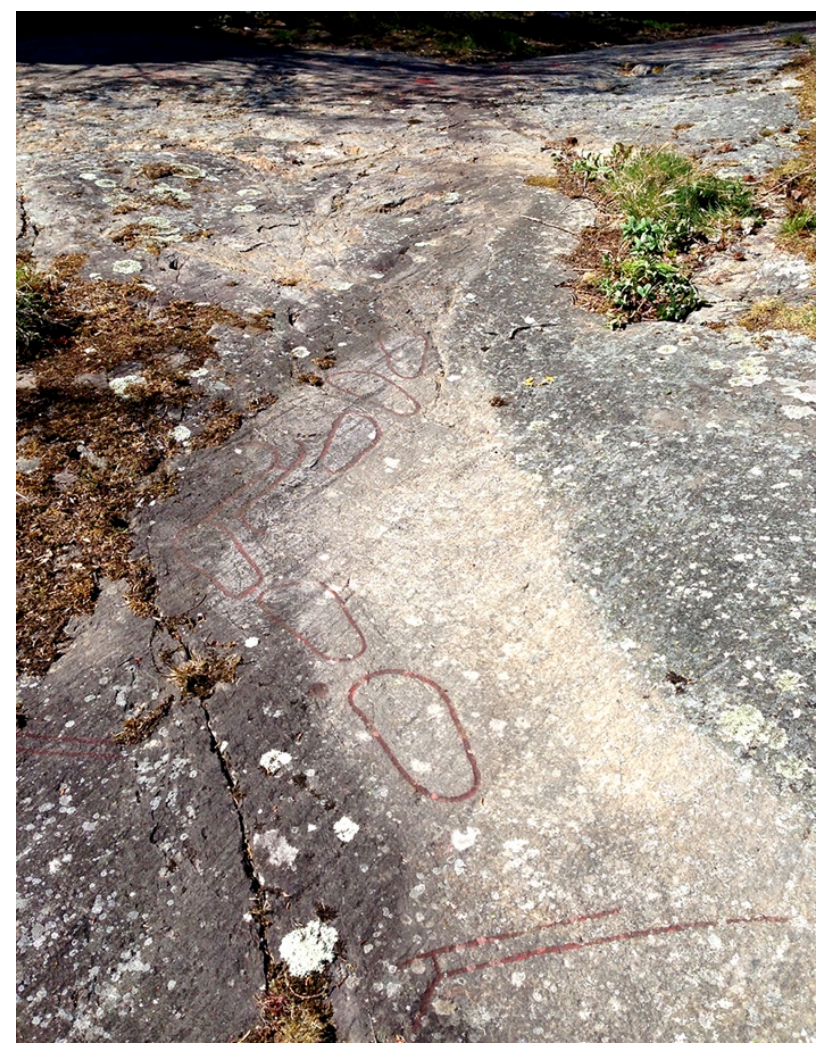

Figure 10. A line of right feet walking down the sloping panel at Boglösa 138:1. Just above the line of feet is a ship. This part of the rock dips to form a channel for rainwater. Photo: C. Nimura

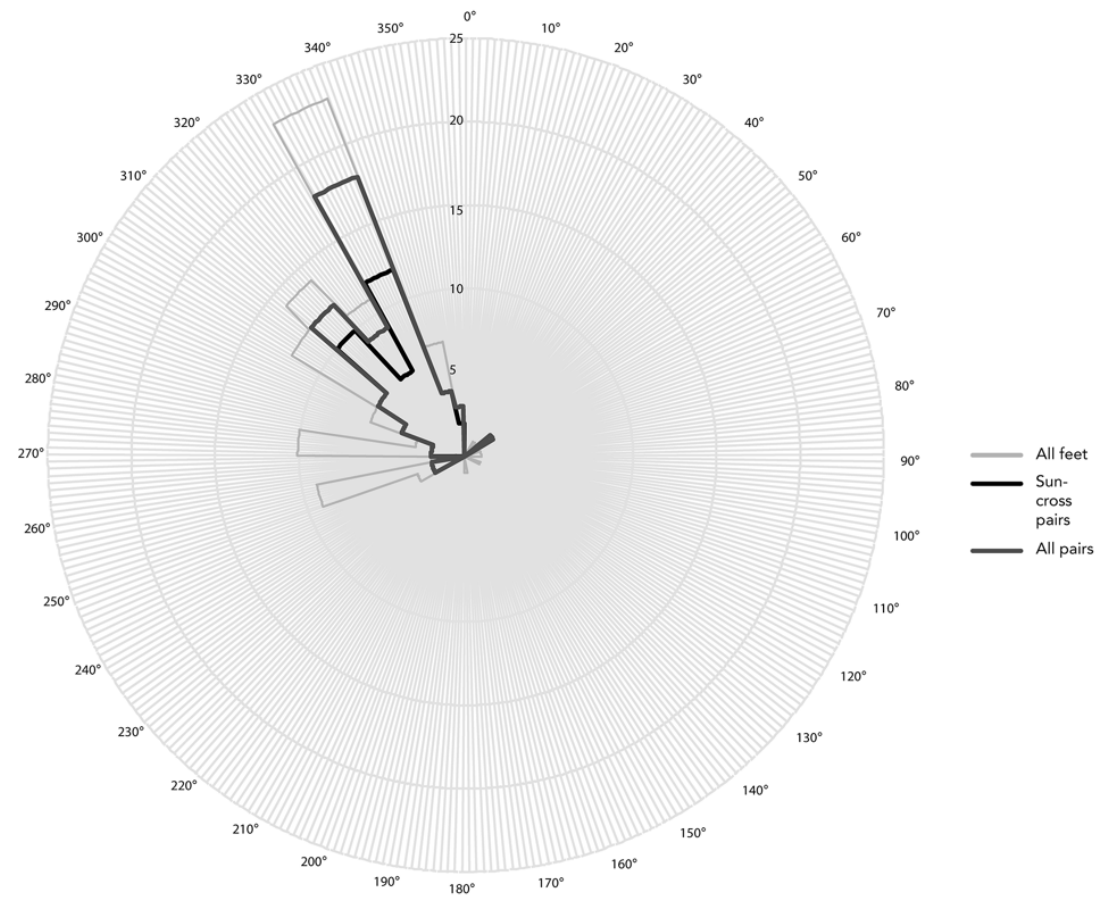

Figure 11. The orientations of pairs of feet and those that look like sun crosses at Boglösa 138:1. Each foot motif is counted individually and grouped in $10^{\circ}$ intervals

${ }^{1}$ Department of Cultural Sciences, Linnaeus University, 39182 Kalmar, Sweden; Email: peter.m.skoglund@lnu.se

${ }^{2}$ Place, Evolution and Rock Art Heritage Unit, Griffith University, Australia; Institute of Archaeology, University of Oxford, UK; Email: courtneynimura@gmail.com

${ }^{3}$ Department of Archaeology, University of Reading, Whiteknights Box 227, Reading, RG6 6AB, UK; Email: r.j.bradley@ reading.ac.uk 